Inger Ulleberg

OsloMet - Oslo Metropolitan University

Ida Heiberg Solem

OsloMet - Oslo Metropolitan University

DOI: http://dx.doi.org/10.5617/adno.5607

\title{
Which questions should be asked in classroom talk in mathematics? \\ Presentation and discussion of a questioning model
}

\begin{abstract}
In this article, we focus on questions posed by the teacher in classroom talk in mathematics. Questions have been shown to be of great importance in developing productive classroom conversations and the students' mathematical thinking. We present a questioning model with four different areas in which specific types of questions can be posed, and relate these question types to other researchers' question categories. Our focus is on the purpose of the question as well as on the kind of answer that is expected. We present how the model can contribute to the understanding of practice through four examples from classroom observations in primary school. Our attention is directed towards movements in the classroom talk, as the four areas of the model are dynamically connected. We discuss how the model can function as an analytical tool for developing and analysing classroom talk in mathematics.
\end{abstract}

Keywords: classroom talk, mathematising, questions, questioning model

\section{Hvilke spørsmål bør stilles i klassesamtaler i matematikk? Presentasjon og diskusjon av en spørsmålsmodell}

\section{Sammendrag}

I artikkelen fokuserer vi på spørsmål som stilles av lereren $i$ klassesamtaler $i$ matematikk. Spørsmål har vist seg å vcre av stor betydning når det gjelder å utvikle produktive klassesamtaler og å utvikle elevers matematiske tenkning. Vi presenterer en spørsmålsmodell med fire områder med ulike typer spørsmål, og vi knytter disse spørsmålstypene til andre forskeres spørsmålskategorier. Vårt fokus er på hensikten med spørsmålet så vel som på svaret som blir forventet. Vi presenterer hvordan modellen kan bidra til forståelse av praksis gjennom fire eksempler fra klasseromsobservasjoner på barnetrinnet. Vår interesse retter seg 
mot bevegelser i klassesamtalen, og å se hvordan de fire områdene er dynamisk knyttet sammen. Vi diskuterer hvordan modellen kan vcere et analytisk hjelpemiddel for å utvikle og analysere klassesamtaler i matematikk.

Nøkkelord: klassesamtale, matematisering, spørsmål, spørsmålsmodell

\section{Introduction}

Our main interest in this article is in exploring classroom talk in mathematics by focusing on the questions asked by the teacher. We are both teacher educators. One of us teaches mathematics didactics and the other pedagogy, and we have collaborated on teaching and research for many years, in close contact with students, teachers and the practice field. We share a common interest in classroom talk and communication, and through observing teachers in the classroom, we became interested in exploring questioning. Many researchers have paid attention to classroom talk, and have explored how to develop high quality in this activity (for example Lampert, Beasley, Ghousseini, Kazemi, \& Franke, 2010; Littleton \& Howe, 2010; Mason, 2000; Mercer \& Hodgkinson, 2008; Penne \& Hertzberg, 2015; Stein, Engle, Smith, \& Hughes, 2008). Alexander claims that dialogues and oral activity have had too little place in the modern classroom and states that "considerably lower educational status is ascribed to talk than to writing" (Alexander, 2006, p. 9). There can be many reasons for this. One possible hypothesis is that it is a challenge for teachers to facilitate dialogue in their teaching. In the research literature, whole class discussions are reported as challenging for the teacher because they involve "a range of important and subtle pedagogical moves” (Boaler \& Humphreys, 2005, p. 49).

Just getting students to talk is not enough. Making one's thinking available by speaking must be followed up by exploring this thinking, and by using the answers given as resources in the continuing talk (Alexander, 2008; Drageset, 2013). Classroom talk can contribute to the process of reflective communication in which the intention behind sharing ideas is to deepen the students' mathematical understanding (Brendefur \& Frykholm, 2000).

How teachers ask questions is a decisive and challenging aspect of their work (Boaler \& Brodie, 2004). Teachers should sensitise themselves about what they wish students to become aware of, and how to provoke this awareness. In this way, students' mathematical thinking can be developed, as well as their awareness of questions that should be asked, even when the teacher is not present.

The teacher's task is to plan classroom talks with mathematical quality and to be sensitive to the fruitful and unpredictable contributions from the students. Classroom talk can be carried out in such a way that thinking is narrowed and controlled, as in the IRE structure. The typical dynamics in an IRE conversation 
are that the teacher takes the initiative (I) by asking a question, the student gives a response (R), an answer, and the teacher evaluates (E) the answer (Mehan, 1979). Through this structure, the teacher maintains control, and conversations will be concerned with the search for the one correct answer. If limited to this kind of conversation, the understanding of mathematics may be limited to rules and procedures.

It is important to develop an inquiring culture, with an open, curious and wondering attitude to the subject, the students, ourselves, the process and the interaction, and with an openness to the unpredictable and risk-taking (Biesta, 2013; Johnsen-Høines \& Alrø, 2012). Having a list of instructive actions as potential steps in a classroom conversation could be helpful, but it is not possible to have a recipe for how to conduct classroom talk (Cengiz, Kline, \& Grant, 2011). It will depend on the teacher's mathematical knowledge, where one crucial element is the ability to identify and act in contingent moments, and to manage situations that are not planned for (Kleve \& Solem, 2014, 2015; Rowland \& Zazkis, 2013). Classroom talk can be carried out in many ways, and some problems and challenges have been identified. Research suggests that there are few cognitive challenges in classroom talk, that students are given little time to think, and that classroom talk tends to be monological and authoritative (Aukrust, 2003; Boaler, 2003; Streitlien, 2009).

\section{Why questions?}

Classroom talk can be analysed from different perspectives, and the questions the teacher asks the class are one dimension of classroom talk. Research shows that the teacher's questioning is crucial with regard to the challenges the students are given, and that creating an enquiring classroom culture can be supported by teachers' questioning (Boaler \& Brodie, 2004; Lampert, 1990; Moyer \& Milewicz, 2002). "Questions at every level, from early school through post-graduate studies, can be posed in a routine way so as to obscure mathematical thinking, or in a manner which reflects mathematical thinking and mathematical structure" (Mason, 2000, p. 103). The questions the teacher asks in the classroom, play a crucial role in developing mathematical conversations and thinking, and are thus worth devoting attention to.

Many studies on questions in mathematic teaching use dichotomies, such as open or closed questions, test questions or genuine questions, rhetorical or authentic questions, and questions with low or high cognitive challenges (described in f.ex. Ainley, 1988; Boaler \& Brodie, 2004; Streitlien, 2009). The advantage of such a dichotomy is that it is easy to relate to, while it can be a disadvantage that it does not capture the nuances in the teaching.

Other researchers have developed more complex typologies of questions. Watson and Mason (1998) operate with six main categories, each with eight 
sub-categories, making a total of forty-eight categories. All the questions in their model are concerned with justification, hypothesising, argumentation and convincing. Niss and Jensen (2002) have many examples of questions connected to the eight different areas of mathematical competency they have developed, while Boaler \& Brodie (2004) have nine different categories of questions derived from analysing teaching. These complex categories can be helpful in the preparation and analysis of classroom talk, but they can be too complex to be used by teachers in action. We later place some of these question types within the model presented here.

Against this background, we want to contribute to the discussion about questions in classroom talk in mathematics through a model that can function in action as well as in preparation and analysis (Solem \& Ulleberg, 2013). Our question in this article is: How can this model contribute to analysing and developing classroom talk? First, we present the model that can be an analytical tool that teachers can use to reflect on their own teaching. We then provide examples of how this model can contribute to the understanding of classroom discourse, and discuss some issues concerning the model.

\section{Developing the model}

\section{Rationale for the model}

In looking for a model, we wanted it to comprise certain dimensions that could enhance the teachers' reflections on their teaching. We wanted it to be possible to discuss and analyse all kinds of mathematical questions that teachers ask in classroom talk, questions involving both low and high cognitive demands. Teaching is an intentional endeavour, and we were interested in developing a model that could support the teachers in exploring the intentions they have with their questions, and through this become more aware of their questioning. The intentions can differ from checking the outcome of a task, following progression in the textbook, explaining and sharing strategies in class, to challenging students to explore, justify and prove, and to build common ground in the class. How can these varying intentions be included in a model? At the same time, we wanted to include the teachers' expectations to the answers the students would come up with to the questions asked. Does the teacher expect certain answers to certain questions, so that we can speak of closed or rhetorical types of questions, or does the teacher ask open or genuine questions, where the answers can be unpredictable and surprising?

We also wanted to develop a model that could be easy to remember, while at the same time encompassing the complexity we find in the categories described by, for example, Ainley (1988), Mason (2000), Niss and Jensen (2002), and Boaler and Brodie (2004). The teachers could have this model in mind when both planning and carrying out teaching. 


\section{The model}

Since the 1980s, the Canadian professor and family therapist Karl Tomm has been interested in questioning in different professional activities and areas, such as supervision, therapy, training in leadership, and coaching. Over the years, he developed a model of systemic questioning (Tomm, 1988), which is still under revision (Hornstrup, Tomm, \& Johansen, 2009). He says: "It seems reasonable to assume that a network of assumptions and presuppositions concerning the issues being asked about exists in the mind of the therapist as a foundation or rationale for the question" (Tomm, 1988, p. 3). The purpose of the model is for the practitioner to reflect on and clarify the background to asking a question, and Tomm's model uses two axes. The vertical axis deals with basic assumptions behind a question and uses the endpoints "linear" and "circular" understanding or assumptions, with reference to systemic thinking (Bateson, 1972). The horizontal axis captures the question's purpose, on a continuum where the intention is mainly that the practitioner on one side wants to orient himself on the clients' thinking or understanding, towards a position where he wishes to influence the client. These two axes combined form a cross with four areas within which we can identify different questions.

This model contains some of the elements we were searching for. The first element was the axis of the questioner's intentions with the questions, from orienting intentions to influencing intentions. The other element was simplicity and visual clarity, represented by the two axes that Tomm uses to present four different types of questions. Taking this model as our point of departure, we adapted it to fit classroom talk. We changed the endpoints of the vertical axis from "linear-circular" assumptions to "teacher knows the answer - teacher does not know the answer". The focus of the model is on the teacher and the teacher's intentions with the questions and position with regard to the possible answers. This axis can be related to the dichotomies closed and open questions or rhetorical and genuine questions (Streitlien, 2009), but it will work as a continuum on which there can be fluid transitions between the teacher's expectations of the answer. On the vertical axis, the focus is on the teachers' relationship to the answer, whether they know the answer to the question they are posing, or they do not know the answer and are curious about what the students might come up with.

On the horizontal axis, the focus is on the intention or purpose with the question. On the left-hand side of the axis, the teacher's intention behind the question is to orient herself on what the students remember, know, how they think or make sense of the topic or challenge, what strategies they use and so on. On the right-hand side, the teacher's intention when asking a question is to influence or push the students' thinking further. Here we find questions with clear influencing and challenging purposes. This will encompass questions that instigate the students to think further, to explore, explain, justify and discover new connections. This can be connected to what Ainley calls a "directing 
question: to provoke the subject to think further about a problem” (Ainley, 1988, p. 93).

If we connect the axis to the time aspect, we can say that on the orienting side, the teacher often asks what the students have already thought or found out. The question is asked in the past tense and concerns where the students currently are. On the influencing side, the teacher asks questions to promote further thinking; these questions are put in the future tense.

When we put the two axes together, we end up with a cross with four areas with four types of questions:

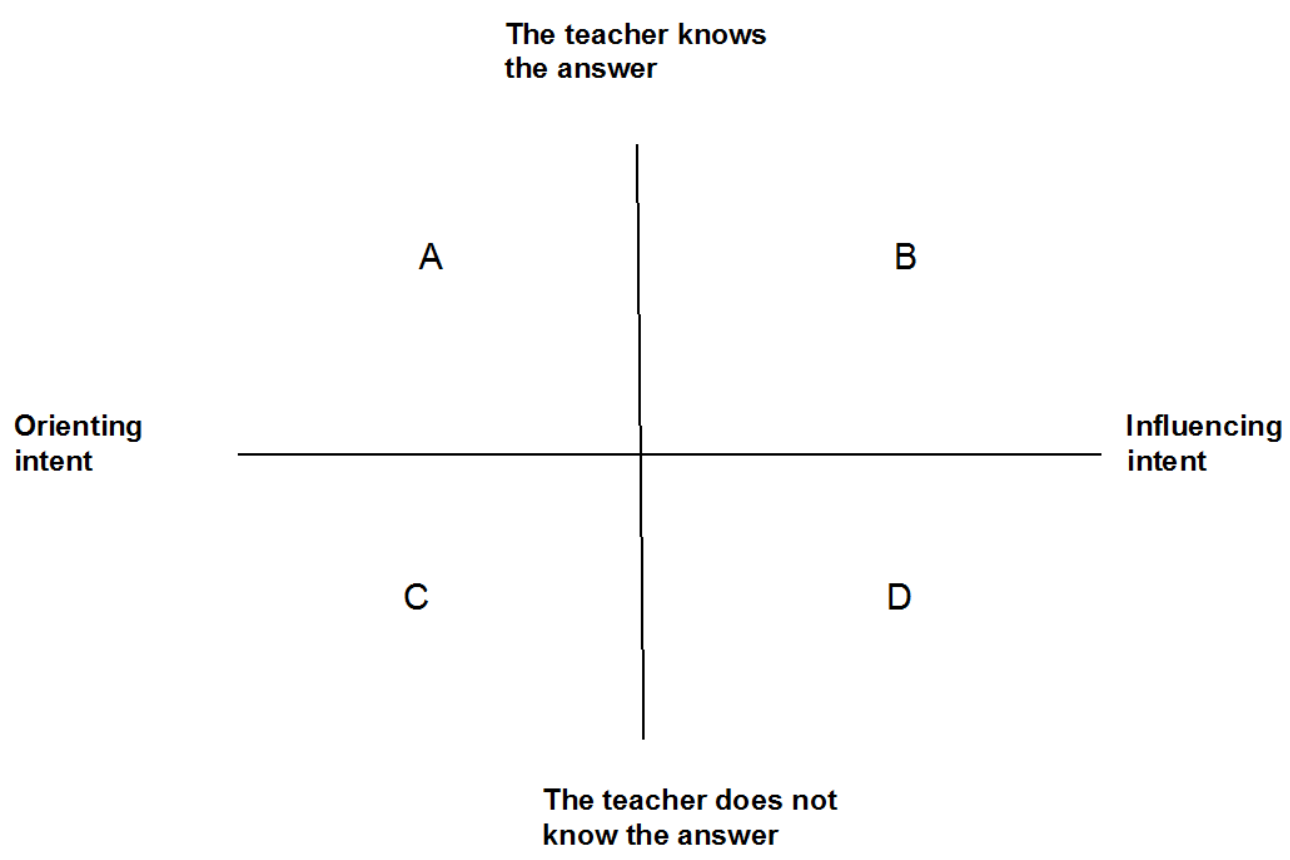

Figure 1. The questioning model

We talk of areas rather than categories, as we see that questions can be contextualised and perceived in different ways. The two axes should be understood as continuums, so that one question can clearly be placed at one end of the axis, while another can be in the middle, for example because it has more unclear or multipurpose intentions. As a questioning model, it can also support the idea of movements and processes in classroom talk, where the dynamics and movements between the areas are of more interest than the mere categorisation of questions. We first present questions from each area and connect them to other models of categorising questions before investigating the movements and dynamics between the areas.

\section{Area A}

This area covers questions that are typical in an IRE conversation, where the teacher knows the answers to the questions posed, and the reason for asking them is to check whether the students have understood or can remember the correct answer. These questions will often carry low cognitive expectations, as 
they invite the students to come up with, remember or recall the right answers. Examples of such questions are:

- What is the answer to the assignment?

- What is this triangle called?

- What is the formula?

- Which number fits here?

- What did we use this for?

These questions relate to what Boaler and Brodie call gathering information or checking (Boaler \& Brodie, 2004), test questions (Ainley, 1988; Mason, 2000), calculation, labelling, and rhetorical questions (Streitlien, 2009). The teacher is asking for something the students already know, remember or think, and we can connect it to the past, to thinking that has already happened.

\section{Area B}

In this area, we find questions whose purpose is to influence and challenge students' thinking in certain directions. The teacher wants the students to mathematise, to discover connections and patterns, and to learn to argue and justify. Examples of questions in this area are:

- to discover connections: "Does this rule apply to all numbers in the grid? Why/why not?"

- to explore a problem: "What happens to the area if you double the length of each side? Why?”

- to justify: "Why do even and odd numbers produce such different results?”

- to argue: "What reasons can you give for that?"

In this area we find questions that can be associated with or connected to "strategic questions" (Tomm, 1988), “directing-structuring questions” (Ainley, 1988), "why/what for/how come questions” (Alrø \& Skovsmose, 2006), "asking for focusing”, "asking as enquiring” (Mason, 2000), "exploring mathematical meanings and relationships", and "linking and applying" (Boaler \& Brodie, 2004). We can also connect these questions to the idea of leading or channelling the students towards specific discoveries (Wood, 1998).

When using questions from the $\mathrm{B}$ area, the teacher guides the students in the directions that she has planned, and can push the students to discover important aspects of the topic/theme/subject at hand. Many of the questions asked in mathematical talks will be in this area, and the teacher must have both specialised mathematical knowledge and knowledge of students' thinking to create challenging and rich conversations (Ball, Thames, \& Phelps, 2008).

This area can be connected to what Mellin-Olsen (1989) called piloting or guiding questions, where the teacher leads the student step by step to the right 
answer. If mainly B-questions are used in classroom talk, the conversations can feel safe for the teacher and contain few surprising elements, and can lead to a class culture dominated by the need to answer correctly. With questions in this area, the teacher is pushing the students further, into the future, and to think then and there.

\section{Area C}

The third area is characterised by a not-knowing position on the part of the teacher, in which she orients herself in the students' mathematical thinking and the strategies they use to solve problems. The teacher does not know the answer, but is interested in how the students think and argue, how they connect or link knowledge, what strategies they use to solve problems, and the explanations or justifications they have for their strategies. This exploration is crucial to be able to ask students especially tailored or customised follow-up questions from the B area. Questions in the $\mathrm{C}$ area can be:

- How did you solve this problem?

- Can you explain how you found your answer?

- Why did you do it that way?

- Has someone done it differently?

- How have you justified that this is right?

Through this questioning, the teacher connects with the students' mathematical understanding at different levels, and explores and researches this properly. At the same time, these questions invite and encourage students to put their thinking into words and share their explanations and strategies with one another. These questions fall into the category "authentic/genuine questions" (Dysthe, 1995; Streitlien, 2009) and what Boaler and Brodie categorise as "probing: getting students to explain their thinking" and "generating discussion" (Boaler \& Brodie, 2004). It is important that the teacher adopts an attitude of curiosity towards the students' thinking, and, through C-questions, expands her understanding of children's mathematical thinking. Experienced teachers will, of course, have heard much of the children's thinking before and will have expectations about what they might answer. But they will not necessarily know what a specific student will think, and new solutions can always emerge. Here, the teacher operates in the past tense, exploring what the students have already thought in their problem-solving or mathematical work.

\section{Area D}

In the $\mathrm{D}$ area, the teacher challenges the students to think further and influences them to explore a task or a question without directing them. The reflections can take unexpected directions, and here we are moving towards an explorative endeavour where the teacher does not have the answers. In some cases the 
teacher moves into fields where she actually lacks the mathematical content knowledge, and yet dares to explore the situation together with the students. More often the teacher has the mathematical content knowledge, but encourages the students to explore the field on their own. She does not know what the students can come up with. We can connect this to dialogical teaching, where all parties learn something new, including the teacher (Alexander, 2008; Alrø \& Skovsmose, 2004; Barnes, 2008; Freire, 1970; Scott, 2008). The questions are often characterised by a what-if-formula, and examples can be:

- What if you choose different numbers?

- What if you choose different strategies?

- What other solutions/strategies can you find?

- What if you choose one of your group's ideas and explore that further?

- Can you find new questions to this situation?

The questions are authentic, and are characterised by being "hypothetical", "expansive" and "promoting independent thinking" (Alrø \& Skovsmose, 2006) and what Mason (2000) calls "asking for enquiring". In this area we also find what Tomm calls "reflective questions" where people are invited to reflect upon their own thinking and explore and develop new perspectives and options (Tomm, 1989).

The teacher can think in the future tense and push the students to think there and then in the public sphere of the classroom, and push them to build this thinking on each other's efforts. This can lead to unsafe and challenging conversations, which will rely on a supportive and inclusive classroom atmosphere. On the other hand, moving into the D area can help to create classrooms that are open to unfinished, unclear and experimental thoughts, arguments and ideas.

\section{Summing up the areas}

If we, for example, ask some students to calculate $42-18$, we can ask questions in the different areas such as: 


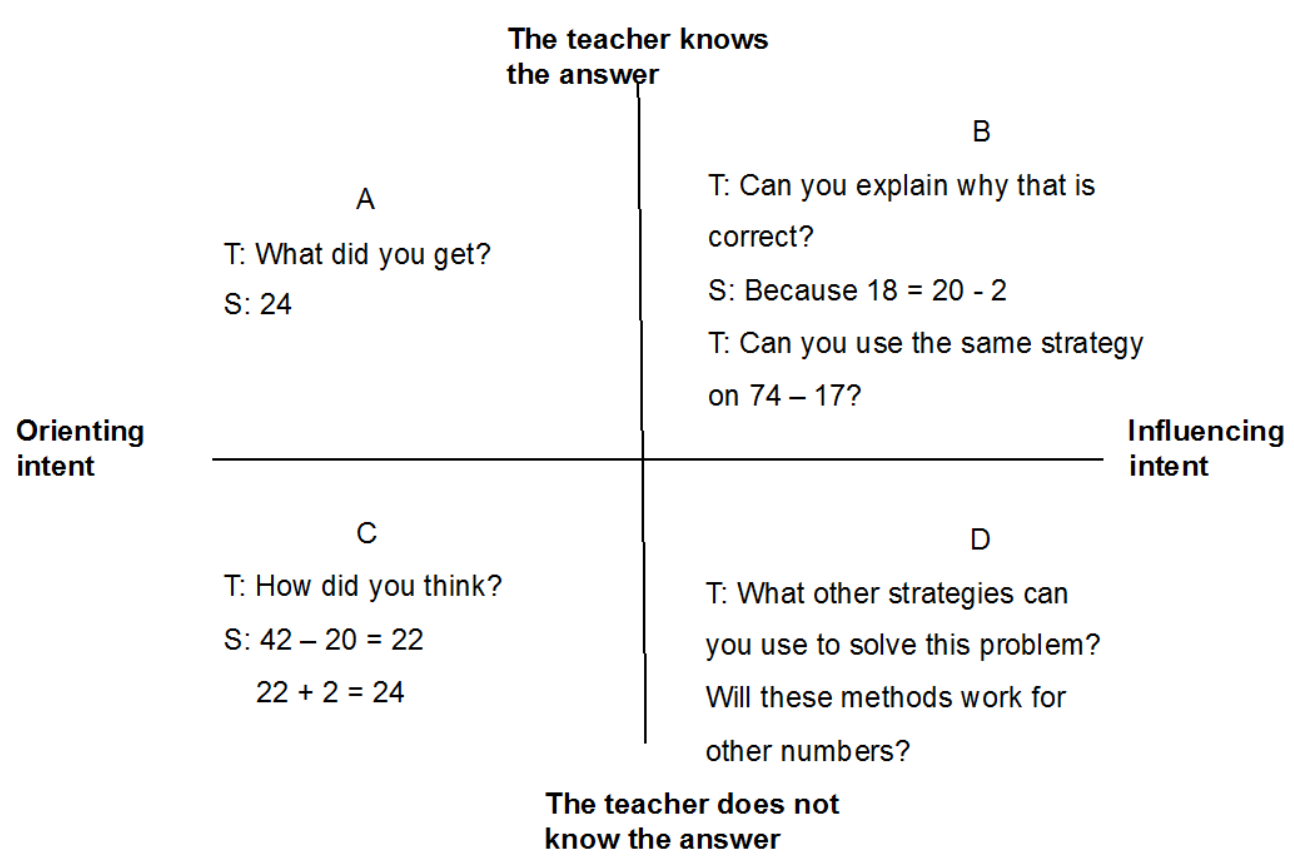

Figure 2. The questioning model - an example

Here, the talk could start in A just to get the answer, and continue in $\mathrm{C}$ to explore the student's thinking. Then a move could be made to B by asking for justification for the student's thinking and challenging the student to try the same strategy on new and different examples (85 - 26 will probably be better solved using a different strategy), and it could end in D where different numbers and strategies are explored. In other conversations, the moves could be different, and the conversation could alternate between B and C, where the teacher systematically challenges each answer the students come up with.

In some conversations, the teacher will mostly be in the B area (challenging the class to discover some connections), in the $\mathrm{C}$ area (exploring the strategies and thinking students have employed in their work) or in the D area (moving into uncharted waters together with the students). Most conversations, however, will move fluently between the areas, and we comment on this later. We now use four empirical examples to demonstrate use of the questioning model before we discuss some aspects of the four different areas and the relations between them.

\section{Exploring through examples}

We now explore how we can elaborate on the use of the questioning model as an analytical tool by presenting some examples from classroom talk. The four examples have live classroom talk as a point of departure, and build upon classroom observations. The observations have been carried out by the authors in primary school classrooms. The examples are chosen because they give opportunity to exemplify the areas of the model in different ways. In examples 1 
and 2 the teachers orient themselves about the students' thinking through questions from the $\mathrm{A}$ and $\mathrm{C}$ areas, but they miss some opportunities to push the students' thinking further. We show how the teacher could continue the classroom talk, using the model. Examples 3 and 4 show how teachers explicitly challenge the students through questions from the B and D areas of the model.

\section{Example 1}

A teacher in fifth grade in primary school asked her students to calculate $14 \times 7$, using their own methods. After a while she asked the students what answer they had found (A-question), and they answered "98". She then asked them to describe their methods to find the answer (C-question). The students presented the following strategies:

$$
\begin{aligned}
& \text { (1) } 7 \times 7=49 \text { and } 7 \times 7=49 \text { and } 49+49=98 \\
& \text { (2) } 7 \times 10=70 \text { and } 4 \times 7=28 \text { and } 70+28=98 \\
& \text { (3) } 7 \times 10=70 \text { and } 70+7=77 \text { and } 77+7=84 \\
& \text { and } 84+7=91 \text { and } 91+7=98
\end{aligned}
$$

Figure 3. Examples of strategies

In this situation, the talk started in A just to get the answer, and continued in C to explore the students' thinking. In this situation the students shared their strategies, and this open strategy sharing is important in helping the students to expand their repertoire. This teacher did not follow up with further questions to challenge the students' mathematical thinking through comparing the different methods by posing questions from the B area: Which of the three methods is most efficient. Is one of the methods specifically adapted to the numbers in this task? Which method is the easiest to generalise? Method 1 has as a point of departure the fact that 14 is an even number. $13 \times 7$ cannot be solved with exactly the same strategy, but how can a similar strategy be developed $(6 \times 7+7$ $\times 7)$ ? How can method 2 be applied to $13 \times 7$ ? In a further development of the classroom talk the teacher could move to area D in asking the students to explore larger numbers or to develop other methods. Using the model, we can suggest the following questions in areas B and D with method 1 as a point of departure: 


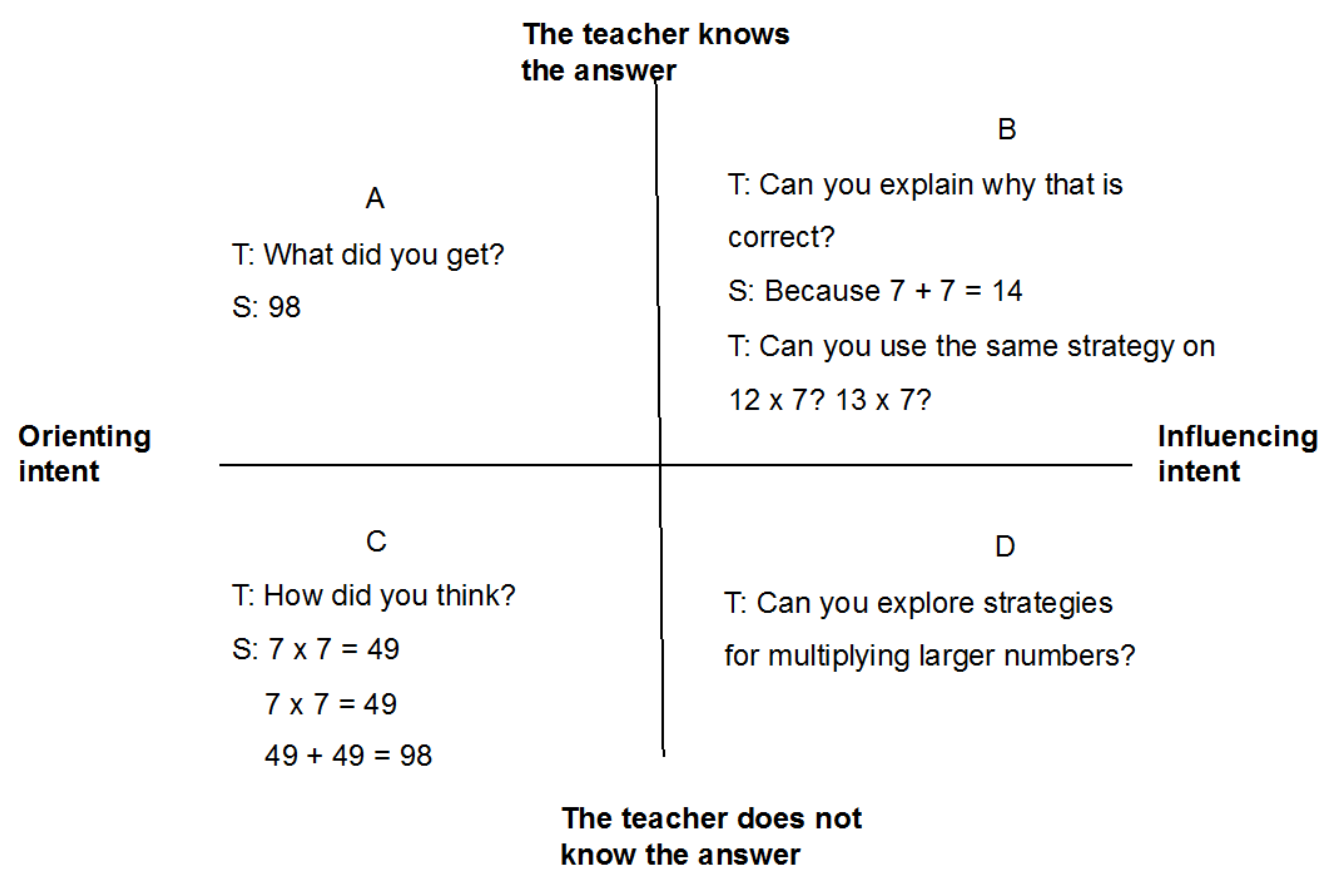

Figure 4. Example 1

\section{Example 2}

A teacher in grade 5 gave the class the task of colouring the 4 times table yellow and the 6 times table blue in the same 100-square grid.

\begin{tabular}{|c|c|c|c|c|c|c|c|c|c|}
\hline 1 & 2 & 3 & 4 & 5 & 6 & 7 & 8 & 9 & 10 \\
\hline 11 & 12 & 13 & 14 & 15 & 16 & 17 & 18 & 19 & 20 \\
\hline 21 & 22 & 23 & 24 & 25 & 26 & 27 & 28 & 29 & 30 \\
\hline 31 & 32 & 33 & 34 & 35 & 36 & 37 & 38 & 39 & 40 \\
\hline 41 & 42 & 43 & 44 & 45 & 46 & 47 & 48 & 49 & 50 \\
\hline 51 & 52 & 53 & 54 & 55 & 56 & 57 & 58 & 59 & 60 \\
\hline 61 & 62 & 63 & 64 & 65 & 66 & 67 & 68 & 69 & 70 \\
\hline 71 & 72 & 73 & 74 & 75 & 76 & 77 & 78 & 79 & 80 \\
\hline 81 & 82 & 83 & 84 & 85 & 86 & 87 & 88 & 89 & 90 \\
\hline 91 & 92 & 93 & 94 & 95 & 95 & 97 & 98 & 99 & 100 \\
\hline
\end{tabular}

Figure 5. Example 2

When the class had done the task, she started out by asking: "Which numbers are yellow?" (A-question). She continued with the question "Why are some squares green?" (B-question), and one of the students came up with the answer "Because if you mix yellow and blue, you get green." That is a valid argument, but not related to the mathematical justification. The teacher wanted to direct the class towards mathematical thinking, and asked them further: "But why are 12 green and 18 blue?” (B-question). Here, the teacher asks for mathematical justi- 
fications, comparing the multiplication tables. The class continued to compare different tables, but were not challenged further.

A follow-up question could be "How can you argue that 12 is in both the 6 times and the 4 times table?”, asking for mathematical answers. The teacher can challenge the students further by asking, "What will happen if we colour the 3 times table in the same grid?”, which will be a B-question. The teacher can also ask the students to try out other tables and look for connections, which could actually function as a D-question, with the teacher not really knowing where the classroom talk will end.

\section{Example 3}

A classroom talk can start with a B-question, as in this example from grade six. The teacher asked, "What is a circle?" One student answered "A figure with no edges", and another one said "A figure without corners and with only one edge." The teacher then drew this figure, and asked "Is this a circle?"

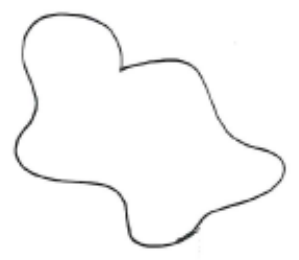

Figure 6. Example 3a

One student then answered "It has to have 360 degrees", and another student said "It has to be round, not with humps like that." The teacher drew, and asked, "Is this a circle?!

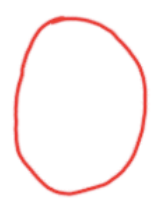

Figure 7. Example 3b

Then a student answered: "No, it has to be completely circular." The class then discussed aspects of the circle, such as the centre of the circle, comparing it to a pizza, the fairness of equal pieces and how to achieve that, and they landed on the explanation that what made a circle circular was that all the lines from the centre to the edge must be of equal length.

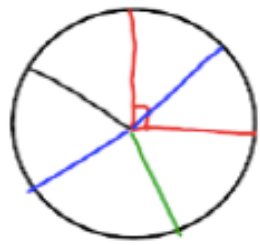

Figure 8. Example 3c 
The teacher systematically asked counter-questions from the B area that led the students to revise their arguments. It is not enough to define a circle as "round" or "without edges". The definition needed further clarification, and the students learned to formulate arguments that were valid.

\section{Example 4}

The following situation occurred in a grade 7 class as they were exploring rational numbers. The teacher had prepared a question in area B: "Can you find a fraction bigger than $3 / 5$ but smaller than $4 / 5$ ?" He had anticipated that the students would solve this problem by finding equivalent fractions with denominators of 10. Something surprising happened: some students discovered that they could find such a fraction by adding the numerators and the denominators separately, and they remembered that they had actually used this method before. One student said: "It happened before too, but you said it was a coincidence." The teacher answered: "Maybe there is a pattern here? Let's try with other numbers."

Here, the teacher asked a D-question, and this further directed the classroom talk. After trying out different numbers and fractions, the pattern worked well, and the teacher summed up the discussion by posing a new question in the $\mathrm{D}$ area: "OK, we can see a pattern here now. However, are we sure that this applies to all fractions?" He commented further: "You know, now we're in an area I haven't checked either. Nor do I know for sure where this will end. I don't see all the patterns here either."

In this example, input from the students gave the classroom talk a new direction and led the teacher to explore uncharted waters together with the students. As a result of this, the students were creative and were given a possibility to develop confidence in their own abilities. The teacher told us that his intention also was to stimulate the students' reflection and independent choices concerning further mathematical exploration. The teacher had the courage to ask the class D-questions and to admit that he still had something to learn. By doing this, he served as a role model by not knowing the answer, as a learner and as an explorer in mathematics.

\section{Discussion}

\section{Normative and analytic use}

When using this model, we can alternate between an analytical and a normative approach to teaching (Imsen, 2016). With an analytical approach, we can explore what actually happens in the classroom, analyse it and try to understand and make sense of what we see and hear, as we have done in the examples. This can inspire reflection and form a point of departure for discussions on what happens and further actions. With a normative approach, we connect the 
teaching to values and ideals, and explore what good teaching can look like. In mathematics teaching, open strategy sharing using questions from the $\mathrm{C}$ area is "typically the first way to get mathematical discussions going in classrooms" (Kazemi \& Hintz, 2014, p. 17). This is however not sufficient to develop the students' mathematical thinking, and challenging the students with questions from the B and D areas is necessary to support the students in learning to justify, explore, connect and develop their strategies (Drageset, 2013; Smith \& Stein, 2011).

Developing classroom talk in mathematics, we can make use of both an analytical and a normative approach of the model. Taking what actually happens as our point of departure, we can discuss how this can be understood and which moves to make to improve the quality of the classroom talk. This can be connected to the significance of developing learning communities and professional conversations in schools (Mausethagen, 2016; Wenger, 1998).

\section{Dynamics and movements}

We claim that there are no wrong questions to ask, it depends on where in the talk the question will work. Questions from all the areas in our model could serve a purpose at the appropriate moment. When analysing classroom talk, we were interested in the movements and the dynamics of the communication. Some conversations can start in area A to check what results the students have come up with, can move to $\mathrm{C}$ to explore their thinking, and then alternate between $\mathrm{C}$ and $\mathrm{B}$ to challenge the students further. Other conversations can start in $\mathrm{C}$ to explore students' different strategies and move to $\mathrm{B}$ to challenge them further. When the teacher discovers that the class needs to repeat some concepts or formulas, they can move to the A area to form a common ground for the class.

In Example 1 the teacher moves from area $\mathrm{A}$ to area $\mathrm{C}$, and it is evident that the teacher needs to ask questions in the $\mathrm{C}$ area, and to understand and interpret the answers to be able to move on. Suitable and interesting questions from the $\mathrm{B}$ and $\mathrm{D}$ areas build on the answers the students come up with in the $\mathrm{C}$ area, such as the three solutions to $14 \times 7$. When the teacher in this manner facilitates learning in the class, she must understand students' mathematical thinking. She must have solid mathematical and didactical knowledge to be able to lead classroom talk in which the students are invited and stimulated to engage in mathematising (Ball et al., 2008; Solem, Alseth, \& Nordberg, 2010; Solem \& Hovik, 2012; Solem \& Reikerås, 2008).

\section{Stuck in one area}

If the teacher is stuck in one area of questioning as a typical pattern in her teaching, she could miss out on some obvious possibilities to further challenge the students and develop helpful mathematical classroom talk. A conversation where questions are drawn solely from the A area could result in a controlled 
classroom talk in an IRE-structured manner, where mathematics is like a collection of rights and wrongs. In a classroom talk in which the teacher only asks questions from the $\mathrm{B}$ area, she could miss out on interesting explanations from the $\mathrm{C}$ area, and not thoroughly explore students' thinking as a basis for further questions from the $\mathrm{B}$ area. In a conversation where the questions are mainly from the C area, we would be part of the "first generation practice", where little attention is paid to guiding the students further (Stein et al., 2008). This does not necessarily lead to mathematising.

In a classroom talk dominated by questions drawn mostly from the $\mathrm{D}$ area, some possibilities of connecting the new questions to former knowledge could be lost. The possibility of mathematising in classroom talk could lie in the dynamics and in the movements between the different areas of questions.

\section{Fluid transitions between areas}

Which questions that belong in the different areas in the model will vary with the context, the class and the students' knowledge, the relationship between the teacher and the individual students, and the differences between the students in the class. The question "Can we divide 19 by 3?" can have an orienting purpose in the A area when posed to pupils in grade 5 to check what they remember, but, asked in grade 2 , the same question can have a challenging purpose in the $\mathrm{B}$ area in terms of getting students to think independently.

Challenges and justifications can be on a low or high cognitive level adjusted to fit the student's position and knowledge. A question such as "What is $14 \times$ 7?" can be challenging for a student in the class who has not yet learned a method for calculation (a B-question), but trivial for a student familiar with such tasks (an A-question). A teacher can ask questions with the intention of finding out about the students' thinking ( $\mathrm{C}$ area), but some students can recognise the question as a challenge to justify and argue, and conceive it as a question from the $\mathrm{B}$ area.

A teacher posing a question that is looking for specific answers (in the B area) can at the same time be open for other perspectives or answers coming up (from the $\mathrm{D}$ area), and the question can be placed on the borderline between the $\mathrm{B}$ and $\mathrm{D}$ areas. The same can be the case as regards whether other questions are clearly in one area or more on the borderline between areas.

Questions asked will always be part of a wider context, and it is not just the question's semantic content or linguistic structure that will decide how it will be interpreted by those who hear it (Jensen \& Ulleberg, 2011; Tomm, 1989; Ulleberg, 2014). Hypothetical questions can only invite exploration and dialogue if there is a culture of curiosity and open thinking in the class (Alrø \& Skovsmose, 2006). A question asking for justification from the $B$ area can function as control and actually stop the students' process of reflection instead of stimulating their creativity and exploration. This is dependent on the classroom culture and established patterns of classroom talk. 


\section{Use of the model}

The questioning model can be used in the preparation of classroom talk, during the talk or after the classroom talk has been carried out. The teacher can explore possible questions connected to a specific task, either alone or with colleagues, and she can prepare questions that will take the task in different directions. In the heat of the moment, the teacher should follow up answers, contributions and questions from the students by exploring their thinking and by challenging them further. Then the model could function as a reminder for the teacher in posing questions from different areas to create dynamics in the conversation. Teachers could also analyse and investigate their own teaching after the talk has been carried out. They could search for patterns in their teaching, expanding their repertoire and looking for lost possibilities.

It is important that the use of the model is not too rigid, and that the teachers keep in mind that students can interpret questions in different ways and perceive questions as more or less challenging. Listening to the students' answers is crucial for teaching, and paying attention to the input from students is a central foundation for the questioning. In this article we connect and discuss the model connected to classroom talk, but it is relevant for conversations in seat work with individuals as well.

\section{Conclusions}

In this article we have tried to show how the questioning model can contribute to the exploration of classroom talk, and be an analytical tool for reflecting on one's own teaching. The teachers could explore their teaching and analyse their questions by asking questions such as: Do I only ask rhetorical questions? (from the A area). Do I invite the students to contribute to the classroom talk by sharing their strategies and mathematical thinking? (from the $\mathrm{C}$ area). Do I challenge the students to explore, argue and justify through my questioning? (from the B and D areas). Do I use the insight I gain from the students' answers to challenge them further in different ways, supporting their creativity and critical thinking? The teachers' exploration of their questions could be an analytical and reflective mode that is connected to arriving at better practices (Ulleberg \& Solem, 2015).

Teachers could also use this model to explore the patterns of movements in mathematical conversations. A teacher who always starts out by asking for the correct answer (A) and then challenges the students (B) without exploring their ways of thinking $(C)$ could be made aware of this pattern by analysing her own teaching with the help of this model. The teacher could then use the model in her preparations, in order to expand the repertoire of questions she asks the class. We wanted to construct a model that is simple enough to serve as a model-inaction, yet complex enough to encompass the different question types for both 
preparatory and analytical use (Solem \& Ulleberg, 2013). How teachers can benefit from this model in their practical work in the classroom remains to be explored more systematically.

To fulfil the intentions of oral communication in mathematics, the students need to have an opportunity to develop mathematical thoughts and ideas in collaboration with others, and, together with others, to try out justifications and arguments. A point of departure for a teacher who wishes to mathematise her teaching could be to explore the questions she asks in the classroom. By doing so, she can also promote the students' participation, critical thinking, independence, and creativity, which is part of the wider objective of the school.

\section{About the authors}

Inger Ulleberg is associate professor in pedagogy at the Department of Primary and Secondary Teacher Education, OsloMet - Oslo Metropolitan University. Her research interests include communication in different educational settings as well as in supervision and counselling.

Institutional affiliation: Department of Primary and Secondary Teacher Education, OsloMet - Oslo Metropolitan University, PO box 4 St. Olavs plass, NO0130 Oslo, Norway.

E-mail: inger.ulleberg@hioa.no

Ida Heiberg Solem is associate professor in mathematics at the Department of Primary and Secondary Teacher Education, OsloMet - Oslo Metropolitan University. Her research interests include children's mathematical thinking as well as communication in mathematics.

Institutional affiliation: Department of Primary and Secondary Teacher Education, OsloMet - Oslo Metropolitan University, PO box 4 St. Olavs plass, NO0130 Oslo, Norway.

E-mail: ida.solem@hioa.no

\section{References}

Ainley, J. (1988). Perceptions of teachers' questioning styles. Paper presented at the 12th Conference of the International Group for the Psychology of Mathematics Education.

Alexander, R. (2006). Towards dialogic teaching: Rethinking classroom talk. Cambridge: Dialogos Cambridge.

Alexander, R. (2008). Culture, dialogue and learning: Notes on an emerging pedagogy. In N. Mercer \& S. Hodgkinson (Eds.), Exploring Talk in School (pp. 91-114). London: Sage Publications Ltd.

Alrø, H., \& Skovsmose, O. (2004). Dialogue and learning in mathematics education: Intention, reflection, critique (Vol. 29). Springer Science \& Business Media. 
Alrø, H., \& Skovsmose, O. (2006). Undersøgende samarbejde i matematikundervisningen: udvikling af IC-Modellen [Investigative cooperation in teaching mathematics: development of the IC model]. Aalborg Universitet: Arbejdspapirer om læring.

Aukrust, V. G. (2003). Samtaledeltakelse i norske klasserom - en studie av deltakerstruktur og samtalebevegelser [Participation in conversations in Norwegian classrooms - a study of structures of participation and movements in conversations]. In K. Klette (Ed.), Klasserommets praksisformer etter Reform 97. Synteserapport [Forms of praxis in classrooms after the 1997 curriculum reform. A synthesis] (pp.77-110). Oslo: Pedagogisk forskningsinstitutt, Universitetet i Oslo.

Ball, D. L., Thames, M. H., \& Phelps, G. (2008). Content knowledge for teaching: What makes it special? Journal of teacher education, 59(5), 389-407.

Barnes, D. R. (2008). Exploratory Talk for Learning. In N. Mercer \& S. Hodgkinson (Eds.), Exploring Talk in Schools (pp.1-15). London: Sage Publications Ltd.

Bateson, G. (1972). Steps to an Ecology of Mind. New York: Ballantine Books.

Biesta, G. J. J. (2013). The beautiful risk of education. Boulder: Paradigm Publ.

Boaler, J. (2003). Studying and Capturing the Complexity of Practice - The Case of the "Dance of Agency". International Group for the Psychology of Mathematics Education, 1, 3-16.

Boaler, J., \& Brodie, K. (2004). The importance, nature, and impact of teacher questions. Paper presented at the twenty-sixth annual meeting of the North American Chapter of the International Group for the Psychology of Mathematics Education.

Boaler, J., \& Humphreys, C. (2005). Connecting mathematical ideas. Portsmouth: Heinemann Educational Books.

Brendefur, J., \& Frykholm, J. (2000). Promoting mathematical communication in the classroom: Two preservice teachers' conceptions and practices. Journal of Mathematics Teacher Education, 3(2), 125-153.

Cengiz, N., Kline, K., \& Grant, T. J. (2011). Extending students' mathematical thinking during whole-group discussions. Journal of Mathematics Teacher Education, 14(5), 355374.

Drageset, O. G. (2013). Mathematics Teachers' Knowledge, Beliefs and Communication. Faculty of Educational Sciences, University of Oslo.

Dysthe, O. (1995). Det flerstemmige klasserommet: skriving og samtale for å lære [The polyphonic classroom: writing and conversation for learning]. Oslo: Ad Notam Gyldendal.

Freire, P. (1970). Pedagogy of the Oppressed [trans. Myra Bergman Ramos]. New York: Continuum.

Hornstrup, C., Tomm, K., \& Johansen, T. (2009). Spørgsmål, der gør en forskel [Questions that make a difference]. http://macmannberg.dk/wpcontent/filer/Spoergsmaal_der_goer_en_forskel.pdf , København.

Imsen, G. (2016). Lererens verden: innføring i generell didaktikk [The world of the teacher: introduction to general didactics], 5th ed. Oslo: Universitetsforlaget.

Jensen, P., \& Ulleberg, I. (2011). Mellom ordene - kommunikasjon i profesjonell praksis. [Between the words - communication in professional practice]. Oslo: Gyldendal Akademisk.

Johnsen-Høines, M., \& Alrø, H. (2012). Trenger en spørre for å være spørrende? [Do you have to ask to be questioning?] In M. Johnsen-Høines \& H. Alrø (Eds.), Læringssamtalen i matematikkfagets praksis. Bok 1 [The learning conversation in the practice of mathematics. Book 1]. Bergen: Caspar Forlag.

Kazemi, E. \& Hintz, A. (2014). Intentional Talk. How to Structure and Lead Productive Mathematical Discussions. Stenhouse Publishers. 
Kleve, B., \& Solem, I. H. (2014). Aspects of a teacher's mathematical knowledge in his orchestration of a discussion about rational numbers. Nordic Studies in Mathematics Education, 19(3 \& 4), 119-134.

Kleve, B., \& Solem, I. H. (2015). A contingent opportunity taken investigating in-between fractions. Paper presented at the CERME 9 - Ninth Congress of the European Society for Research in Mathematics Education. https://hal.archives-ouvertes.fr/hal01289739/document

Lampert, M. (1990). When the problem is not the question and the solution is not the answer: Mathematical knowing and teaching. American educational research journal, 27(1), 2963.

Lampert, M., Beasley, H., Ghousseini, H., Kazemi, E., \& Franke, M. (2010). Using designed instructional activities to enable novices to manage ambitious mathematics teaching. In M. K. Stein \& L. Kucan (Eds.) Instructional explanations in the disciplines (pp. 129141). Springer US.

Littleton, K., \& Howe, C. (2010). Educational dialogues: Understanding and promoting productive interaction. London: Routledge.

Mason, J. (2000). Asking mathematical questions mathematically. International Journal of Mathematical Education in Science and Technology, 31(1), 97-111.

Mausethagen, S. (2016). Om lcererrollen. Fra ekspertgruppa om lcererrollen. [About the role of the teacher. From the expert group about the role of the teacher]. Bergen: Fagbokforlaget.

Mehan, H. (1979). "What time is it, Denise?”: Asking known information questions in classroom discourse. Theory into practice, 18(4), 285-294.

Mellin-Olsen, S. (1989). Kunnskapsformidling: virksomhetsteoretiske perspektiver. [Dissemination of knowledge. Perspectives from activity theory]. Bergen: Caspar Forlag.

Mercer, N., \& Hodgkinson, S. (2008). Exploring Talk in School: Inspired by the work of Douglas Barnes. London: Sage Publications Ltd.

Moyer, P. S., \& Milewicz, E. (2002). Learning to question: Categories of questioning used by preservice teachers during diagnostic mathematics interviews. Journal of Mathematics Teacher Education, 5(4), 293-315.

Niss, M., \& Jensen, T. H. (2002). Kompetencer og matematiklæering: Idéer og inspiration til udvikling af matematikundervisning i Danmark [Competencies and the learning of mathematics: Ideas and inspiration for the development of mathematics teaching in Denmark]. (Vol. 18). København: Undervisningsministeriet.

Penne, S., \& Hertzberg, F. (2015). Muntlige tekster i klasserommet. [Oral texts in the classroom]. Oslo: Universitetsforlaget.

Rowland, T., \& Zazkis, R. (2013). Contingency in the mathematics classroom: Opportunities taken and opportunities missed. Canadian Journal of Science, Mathematics and Technology Education, 13(2), 137-153.

Scott, P. (2008). Talking a way to understanding in science classrooms. In N. Mercer \& S. Hodgkinson (Eds.), Exploring Talk in School (pp. 17-36). London: Sage Publications Ltd.

Smith, M. S. \& Stein, M. K. (2011). Five practices for orchestrating productive mathematics discussions. Reston, VA: National Council of Teachers of Mathematics.

Solem, I. H., Alseth, B., \& Nordberg, G. (2010). Tall og tanke. [Numbers and thoughts]. Oslo: Gyldendal Akademisk.

Solem, I. H., \& Hovik, E. K. (2012). «36 er et oddetall» - Aspekter ved undervisningskunnskap i matematikk på barnetrinnet. ["36 is an odd number” - Aspects of knowledge for teaching in mathematics in primary school]. Tidsskriftet FoU i praksis, 6(1), 47-60.

Solem, I. H., \& Reikerås, E. (2008). Det matematiske barnet [The mathematical child]. Bergen: Caspar Forlag. 
Solem, I. H., \& Ulleberg, I. (2013). Hva spør lærere om? [What do teachers ask?]. In H. Christensen \& I. Ulleberg (Eds.), Klasseledelse, fag og danning [Classroom leadership, subjects and bildung] (pp. 41-58). Oslo: Gyldendal akademisk.

Stein, M. K., Engle, R. A., Smith, M. S., \& Hughes, E. K. (2008). Orchestrating productive mathematical discussions: Five practices for helping teachers move beyond show and tell. Mathematical thinking and learning, 10(4), 313-340.

Streitlien, Å. (2009). Hvem får ordet og hvem har svaret? Om elevmedvirkning i matematikkundervisningen [Who gets the word and who has the answer? On students' participation in mathematics education]. Oslo: Universitetsforlaget.

Tomm, K. (1988). Interventive interviewing: Part III. Intending to ask lineal, circular, strategic, or reflexive questions? Family process, 27(1), 1-15.

Tomm, K. (1989). Systemisk intervjumetodik: en utveckling av det terapeutiska samtalet. [Systemic interviewing: a development of the therapeutic conversation]. Stockholm: Mareld.

Ulleberg, I. (2014). Kommunikasjon og veiledning: en innføring i Gregory Batesons kommunikasjonsteori - med historier fra veiledningspraksis [Communication and supervision: an introduction to Gregory Bateson's communication theory - with stories from supervision practice] (2nd ed.). Oslo: Universitetsforlaget.

Ulleberg, I., \& Solem, I. H. (2015). Hvordan kan lærere bidra til deltakelse og matematisering i klassesamtalen i matematikk? [How can teachers contribute to participation and mathematising in the classroom talk in mathematics?]. In H. Christensen \& R. S. Stokke (Eds.), Samtalens didaktiske muligheter [Didactic possibilities in conversations] (pp. 104120). Oslo: Gyldendal Akademisk.

Watson, A., \& Mason, J. (1998). Questions and prompts for mathematical thinking. Derby, UK: Association of Teachers of Mathematics.

Wenger, E. (1998). Communities of practice: Learning, meaning, and identity. New York: Cambridge University Press.

Wood, T. (1998). Alternative patterns of communication in mathematics classes: Funneling or focusing. In H. Steinbring, M. G. B. Bussi, \& A. Sierpinska (Eds.), Language and communication in the mathematics classroom (pp. 167-178). Reston, Virginia: National council of teachers of mathematics. 